\title{
Costs and Benefits of Proliferation of Christian \\ Denominations in Nigeria
}

\author{
B.A.C. Obiefuna, K.L. Nwadialor \\ \& I.L. Umeanolue \\ http://dx.doi.org//10.4314/ujah.v17i1.2
}

\section{Abstract}

The unbridled proliferation of Churches in Nigeria has steered up concerns among adherents of religious faiths, onlookers and academics alike. Nigerian society today is undergoing significant constant proliferation of Churches which has brought not only changing values, but also source of solutions to people's problems. The origin of this phenomenon could be traced to Martin Luther's 95 theses which sparked off religious revolution in $16^{\text {th }}$ century Europe. Following Luther, Zwingli and John Calvin started reforms in Switzerland; John Lawx in Scotland, also Holland and other countries witnessed the reform. This reform gave rise to the formation of the Lutherans, the Anglicans, and the Presbyterians. The Pentecostals and the independent Churches which proliferated at last also joined. In Nigeria some of them started to surface towards the end of the $19^{\text {th }}$ century. Proliferation of Churches entails multiplicity of Christian religious groups with each founder claiming divine origin of his or her ministry. However, this study has established other factors rather than divine call for Church proliferation. The study has also tried to explore Church proliferation in Nigeria pointing out its costs and benefits and solutions were suggested on how to curtail the trend in order for it not to blow out of proportion. 


\section{Introduction}

An overview of the religious situation in Nigeria suggests that the recent socio-economic and political situation has been a symptomatic of the endemic plurality of Nigeria's religious landscape. The country is now a procreant ground for all kinds of religious movements especially within the Christian faith. The growth and expansion of proliferated Churches in the country has attracted attention of many scholars both within and outside Nigeria, especially since their massive proselytizing by certain groups has won adherents in Europe and America.

Recognized as an off-shoot of missionary Churches and bearing some features of African traditional religion, proliferation of Churches is seen on the whole to constitute pastoral challenge on the entire Church in Nigeria. The founders of these new generation churches always postulate diversified reasons for their emergence and expeditious growth, some say that their call is a divine call from God, while some claim divine visions and dreams, emphasized deeper biblical interpretation and so on. However, it is the opinion of the present researchers that the pivotal factors for the emergence of these newer churches, as well as the costs and benefits of the activities of these new movements to the entire Nigerian society have not been properly investigated and analyzed. Therefore some responsible theological investigations have become imperative, more so at this stage of crucial discussions and debate concerning the gains of religion in nation building. The result of such investigations and evaluations will help towards the establishment of truly stable and authentic Church of Christ in Nigeria.

The thrust of this paper, therefore, is to trace the historical foundations of Church proliferation in Nigeria. The study will also look into various dimensions of Church 
proliferation, investigate the remote and immediate causes of the phenomenon with the aim to highlighting its costs and benefits to the Nigerian people.

\section{Historical Foundations for Proliferation of Churches in Nigeria}

It can be argued that the beginning of new religious movements in Nigeria dates back to the late $19^{\text {th }}$ century and early $20^{\text {th }}$ century as a result of Nigeria's quest for settlement from the colonial government. Historically speaking, one may not ignore the socio-political factors arising from oppression and struggle against colonialism in Nigeria, which gave rise to the emergence and growth of Independent Church movements. The rejection of almost everything African by both the early missionaries and colonizers as 'primitive' unreliable, dubious and fetish really baffled many Africans who saw such an affront as humiliating. More so, the European brand of Christianity was neither satisfactory to the Africans, nor did it provide answers or solutions to certain African problems. Mbefo (2002), analyzing the religious scenario of the period observes that there was dissatisfaction among members of the missionary Churches in the country. Their religious yearnings were not met adequately by the liturgical ceremonies of these Churches. He writes:

The members of the mainline Churches' expectations from the Churches were not met. The missionaries of the older Churches failed to address the type of questions the African situation raised for them: Witchcraft, demon possession, haunting by evil spirits, the cult of ancestors; the use of protective charms, talisman; sorcery and the traditional dancing form of worship at the shrines. The tendency among the missionaries was to dismiss these questions as due to 
ignorance arising from a pre-scientific mentality. (p. 29).

Nmah (2010) further notes that the explosion of proliferated Churches in Nigeria emanated naturally from the religious and political scenario of the country in the late $19^{\text {th }}$ century and the early $20^{\text {th }}$ century. The historical context of these decades is very vital for an in-depth understanding of what may be termed Nigeria's spirit of nationalism. The goal of selfaffirmation was glaringly evident in the projects of the nationalists, seeking liberation from the clutches of the European imperialism. So, this general dissatisfaction among African people opened room for new religious movements encountered among members of the mainline Churches in Nigeria as a whole. And also the desire for a religious experience becomes a continuous phenomenon in Nigeria, compelling people to constantly shift their ecclesial affiliation based on their previous and prevailing religious understanding.

The Christian religion itself exhibits bewildering trajectories. There is the Roman Catholicism, from the former French-German Province of Alsace and Lorraine and later preached by the Irish who were not particularly friendly with the British who themselves spread an Anglican form of Christianity. Then there came the Lutherans, the Presbyterians, the Baptists, indeed a confusing cluster of Churches that claim the name Christian. Since Nigeria itself is an amorphous mass of an ethnic bazaar, one would be inclined to ask what keeps Churches from exploiting this un-united consortium of religious experience (Mbefo, 2001).

Not only was there a scramble for territories among the European colonial powers, there was a parallel scramble for Nigerian souls among the various Christian Churches who 
came from America and Europe. Ekechi (1972) has exploited the competitiveness between the Roman Catholic and the Anglican missionaries to support his thesis of the retardatory effect it had on the development of Igbo language. The Churches shared out the country into spheres of influence such that wherever a Church had come, there it could proselytize. With the coming of the schools and the concomitant mobility of the students and teachers, Nigerian Christians encountered Christian Churches other than the ones they were brought up in. Nigerian students were equally exposed to certain western literature and they read about the history of the Church and the scandal of disunity from the time of Henry viii of England. Not only did they discover Henry viii, they also discovered the courage and audacity of the Reformers, like Luther, Calvin, Wesley and their groups. With such precedents as support, Nigerians who were so moved by whatever spirit it may have been began their own native Christian Churches. Hasting (1976), further observes that:

The multiplication of Churches is a striking characteristic of historic Protestant tradition and it was exported to Africa. Sometimes there were five or six different Protestant missionary groups at work within the same part of a single country and it does look as if it was in areas where Protestant missionary tradition was not multiple that the African response was to produce with great gusto a new multiplicity. Such a response can be seen rather as one of creative fidelity to the tradition than as one of rejection of it. (p. 25).

Hasting believes that the multiplication of Churches is normal in the Protestant tradition, a development not to be bewailed but rather one that continues the Protestant thrust. Mbefo (2001) corroborates that the multiplication is even called for by the specifically African situation, namely; to address the 
African experience of religion prior to the coming of Christianity which was ignored by the missionary Churches. From the bosom of Africa, besides, arose African Christian prophets who knew their background and who were thereby better equipped to handle specifically African religious problems.

\section{Dimensions of Church Proliferation in Nigeria}

The task of grouping these proliferated Churches in Nigeria is not an easy one as authors often differs in their typology of new religious movements in Africa. The matter is made more complex when it is considered that these movements differ in origin, belief, size, behavioural patterns and tenets. However, this section will be devoted to exploring the different dimensions in the proliferated Churches in Nigeria.

\section{The Healing Ministries}

In Africa for instance, there is the tendency to run to God for succor in times of need and insecurity. People look to religion for answers and protection against evil forces like witchcraft, failure in life endeavours, suffering, sickness and death (Ndiokwere, 1994). Some of these new religious movements therefore, seem to be poised to face up these existential problems openly, and to promise instant remedies, especially physical and psychological healing. Such disturbances are usually ascribed to evil forces that are to be cast out through exorcism. In this type of movement, emphasis is on healing, but there is equally stress on faith. Absolute faith in God is demanded for healing to take place, the view is that God heals sicknesses, but He could not be forced to. Ailments that linger on for long may be attributed to lack of faith on the part of the sufferer. In some cases, sickness and disease are results of sin and guilt, in which case the sufferer is demanded to confess his/her sin and repent 
before healing could take place. Many sick people, especially those who cannot afford the exorbitant conventional hospital bills, visit these healing ministries.

\section{Thaumaturgical Movements}

In this group we find elements that derive from humanistic, pagan, occult or Gnostic backgrounds. Here there is a meeting point between the old and the new. To a large extent the prophet healer has come to replace the old traditional diviner and fortune teller. The religious movement of this type is entirely syncretistic in form, borrowing from Christianity, traditional religion, occultism and from oriental religion. Emphasis is placed on wonder-working, magical manifestations, spirit mediumship, interpretation of dreams protection against evil forces, assurance in wide range of mundane practices. Ndiokwere (1994) refers to this group as "Sandwich Religious Movements, with pagan filling and Christian outward form; they result from missionary activities which failed to present the gospel in terms that speaks to the real anxieties and questions of people in their cultural milieu" (p. 13). Thus what appears as Christian is actually a covering like the outer part of a sandwich for the indigenous mythology, which remains intact as the content of the religion.

\section{Sabbatharian Movements}

This group has been flowering in Nigeria from the early 70 s with their principal credo as belief and acceptance of the Jewish Sabbath observances, manifesting outwardly in their white flowing gowns. Sabbath Churches have continued to spring up in every nook and cranny of Nigerian society. Here massive healing activities are conducted and occult practices thrive with reckless abandon. In most cases, this group appears to be anti-Christian and should be lumped together with the revivalist forms such as Godianism, Ogboni 
Fraternity and other secret cults (Ndiokwere, 1994). There are built upon some eccentric messianic figures, who command wealth and influence. These include Godian Onyioha, founder of the Godian religion or Godianism; Hyde Onuaguluchi of God's Sabbath Mission, Obu Obu Olumba or O.O. Olumba, leader of The Brotherhood of The Cross and Star. These neopagan religious movements resemble Church movement, but in fact they have retained so many features of the traditional religion. Their leaders have a peripheral idea of what the true Church can be and these leaders are nothing less than Shamans and diviners. Crosses, Bibles and other Christian ornaments are visible, but these are paraphernalia of the healing or divining art. According to Gilliland (cited by Ndiokwere, 1994):

Besides the almost uncritical use of African charms and symbols these Churches also employ an assortment of worship articles that are associated with Catholicism and various Protestant denominations. There are vestments of one group, the hymn book of another, various uses of the crucifix, along with dances and other emotionalism of ancestral religion. Very little emphasis is placed on the Bible as a code of conduct and almost no attention is given to moral and ethical implications of Christianity. (p. 19).

Much of the aladura Church movement is believed to have veered off into this neo-paganistic movement. Some of their curious worship forms and rituals bear simple old pagan colours and can even be branded demonic by orthodox Christians. Some branches of the Celestial Church of Christ, though Pentecostal in outlook or feature, share much in common with the sabbatharian movements.

\section{The Evangelical/Pentecostal Group}


This is by far the largest of the new religious movements, comprising both the so-called indigenous and the foreign influenced. There are generally of Protestant origin and some of them can readily be identified by their aggressive proselytism and attack on the main-line Churches. Some have expansionist programmes and their use of mass media in a way that looks like commercialization of religion provokes diverse reactions from both the orthodox Christian bodies and non Christians. Often mass healing and miracle witnessing rallies are advertised in the mass media, as evangelist and preachers of both national and international reputes are invited to grace the rallies. Thousands of people attend such rallies, after which some claim they have been physically and spiritually regenerated and born again. Many Christians respond to the appeals and attend these rallies because they find in them answers to their thirst for scripture reading, for singing and dancing, emotional satisfaction and their need for concrete and clear answers.

\section{The End of Time Crusader}

This brand of evangelism or gospel crusade is from the Jehovah's Witness sector Watch Tower International. Manipulating mankind's feelings and fears they predict doom on account of social evils, including corruption in the high places. Most often, they claim that they have resigned from the world because the world's problems, wars and politics are so complex and pervasive that this sect no longer concern themselves with them, thus they claim to be citizens of a better society. A society that Ndiokwere (1994) describes as "Jehovah's New World Theocracy or Kingdom" (p. 31), and therefore owe loyalty to Jehovah God. Consequently they refuse the duties of earthly citizenship. At schools and colleges their children and wards are very difficult to deal with, as they refuse to participate in schools and government 
programmes which they refer to as mundane practices prayers, singing of national anthem, recitation of national pledge, observance of public holidays and so on, (Ndiokwere, 1994).

The approaching end of the world constitutes the centre of their message to believers and non believers. In times of social, economic and political crisis, this group seems to appeal to people on the fringe of society. In fact for them, we are now living at the last days which will see the tribulation of great suffering on earth, after which Satan and his followers will be cast into hell and the saints will live in eternal happiness.

A study of this nature may not have an exhaustive list of the typology of new religious movements in Nigeria in the recent time, but it will suffice to say that to an observant mind, the pace at which Churches are spreading like wildfire in Nigeria is alarming. There is evidence that many are just charlatans looking for a means of livelihood. Many are perhaps genuinely religious. But it is obvious that our society has not become upright. It certainly has not become peaceful.

The Nigerian governments and the umbrella bodies/associations, where these Churches are registered seem not to have control over Church proliferations, activities, and excesses. This has been linked to laws on religious freedom and the implicit view that religion is considered a sacred and private domain or a personal choice only fit for private sphere (Trigg, 2012), with identity and ethnic undertones. Any incautious meddling by government institutions can be seen as incendiary- act aimed at inciting civil unrest which triggers unsavory inter-religious conflicts. It has been advocated that state should be separated from religion, but it is pertinent to state here that the link between religion and state is an inextricable one. This quest for separation to a large extent makes governments not to meddle into religious matters and 
this non-involvement has left some excesses of religious institutions unchecked. This brings to fore, the need for a cursory look at the laws supporting religious freedom in Africa, particularly in Nigeria.

In an era where most scholars tends to see religious freedom from the protective axis or benefits which it accords to religious practices. This paper argue that an unregulated or unchecked religious freedom by governments or lack of regulatory bodies, encourage religious excesses that constitutes societal nuisance, infringements on fundamental human rights, killings and conflicts. Brian, (2012) points out that the rationale for such laws (religious freedom) is to reduce social conflicts, but it appears that such laws tends to contribute to conflicts, rather than reduce it.

\section{Grounds for Proliferation of Churches in Nigeria}

The reality of the phenomenon of Church proliferation in Nigeria is tremendous and as such, a proper investigation into the reasons (real and possible) responsible for the expeditious growth of this recurring decimal is the next focus of this study. Although the founders of these new Christian denominations may advance one reason or the other to disguise their undeclared intention, the present study is of the view that a more scholarly study of these Churches will prove that their founders could have been motivated by certain extraneous factors other than divine call which they often claim.

\section{Socio-Economic Factor}

It seems that possessing of the Holy Spirit is the major factor that brings about the proliferation of Churches in the society. And this can also be seen as an open door for disunity, discrimination and twisting of scripture among the Christians. However, Amucheazi (1986) is of the opinion that: 
One of the major causes of the proliferation of Churches in the present day society is the people's excessive quest for material wealth. Materialism coupled with status consciousness and value orientations that have increased in the modern living have made jobless young men seek means of economic survival through the establishment of Churches. (p. 22).

In Nigeria, there is always a relationship between proliferation of Churches and the contemporary teething economic situation in the country. Many people see Church founding as the easiest way to beating down the biting economic crunch. Unemployment and youths restiveness often lead to the formation and establishment of Churches which is the quickest way to get rich and be employed.

It appears that, the rate of unemployment in Nigeria is one of the main factors that create room for the rapid multiplication of new religious movement. Some lazy ones and those who are not comfortable with their mother Churches and even those been sacked from their places of work see opportunities to open to themselves Churches. Thus, this has been a means to deal with poverty and also means of one choosing himself, claiming to have a divine call, just for them to balance their economic gain and to be self employed without any other person's control.

Essien (2010) notes that this growth of proliferation of Churches is not unconnected with economic bases; religion has become a top bracket business in Nigeria and the key players in this situation do not accept the economic reasons as the basis of their action. Rather they argue that their action is purely based on a spiritual dimension, which has proved not to be such. Obiora (1998) describes commercial tendencies of these religious founders as "Holy Deceit"; the art of trading in God's name. The mad craze for money has made some people 
willing to commercialize religion for their own benefit and interest. Many vulnerable people have fallen into the trap of this unholy merchandize.

According to Iwe (1991). "In Nigeria the spirit of materialism is fast invading and shadowing our traditional values and Christian ethics; traditionally our society laid more emphasis on spiritual and social dimension of human nature and value" (p. 28). The truth is that the quest to accumulate wealth and right of liberty has thrown away some Christians' faith; values and norms that guide Christians most especially these founders of new independent Churches in our society. Instead of laying more emphasis on the spiritual growth of the people, some of them emphasize more on material needs. Therefore, the quest for property ownership has been one of main key factors for proliferation of Churches in contemporary Nigeria. However, materialism connects with status consciousness and some other notable factors to heighten the tendency for Church proliferation in Nigeria.

\section{Status Consciousness}

Status consciousness has been identified as one of the major causes of proliferation of Churches in Nigeria. This is an ingredient of African culture that the Europeans called "African disease". It is the general expectation that individuals earn respect and recognition through their performance and what they are in the society. In Nigeria, this urge for recognition may have reached epidemic proportions. Many of the Churches forbid their members to take traditional titles. But Church members consider themselves alienated from their rightful positions in their society without such traditional titles. Many Churches have tried to find parallel titles as dynamic equivalent. Energy has been spent to resurrect for Africans the medieval knighthoods that marked the age of chivalry and the crusades, but the craving has refused to 
assuage, (Mbefo, 2001). People point to the Apostles and Patriarchs, to the Archbishops and Cardinals, to the Senior Apostles, the Vicar Generals and the Mother Superiors. Hence evidence abounds to show that some Churches have arisen out of the desire of some to be Founders and General Overseers and through it to command a congregation of followers.

\section{Quest for Cultural Identity}

Many of the first generation Christians had a strong allegiance to the culture which had formed them before they encountered Christianity. Although they accepted the Christian faith, they nonetheless were not convinced that their new faith should alienate them from their original cultural settings. It was evident that not many European missionaries understood or even tried to understand and appreciate African cultures. According to Mbefo (2001):

Many of them shared the sentiments packed into the imperial mandate namely, "the Whiteman's burden" which entailed the task of civilizing the natives; although the white missionaries may have experienced the Africans' hospitality and friendship, nevertheless their prejudice remains that Africans were noble savages. (p. 104).

But Africans never understood themselves in light of savagery, neither did their experience with the white man, whether as missionary or imperial agents, disposed them to see the Europeans as nobles. The experience of cultural pride and the urge to retain the black man's identity urged the more courageous Christian to affirm their Africanness together with their Christianity. If the retention of this two-fold heritage meant expulsion from European form of Christianity, then they were ready and willing to found African Christianity. Hence the road to the multiplication of Christian 
denominations in Nigerian can be traced to identity consciousness.

\section{Prosperity Preaching}

In the recent past, a new breed of prophets has sprung up whose message is to realize the hopes of heaven here on earth. Their God is not a poor God, nor is he a God of the poor. The sign of God's blessing is the flashy cars, the impressive mansions and the expensive clothes they wear. They promise to make their followers millionaires. It is to this that Nwadialor and Umeanolue (2013) aver that:

In this world that dominated by the godless and the greedy, and populated largely by the ignorant and the destitute, it is easy to see how the materialistic gospel can very quickly become the gospel of the majority. This is particularly so because we live in a society that is flamboyant, a society that worships wealth or money or possession. The increasing worldliness of our society today is such that a focused preacher-one of a rare breed today-who devotes more than a few sentences talking about heaven and hell, and less about God's readiness to give us unlimited prosperity, is probably unlikely today to be able to retain a viable congregation for long. (p. 31).

This is an evidence to show that prosperity and new believe about faith had led many Church founders into adaptation of new preaching of the gospel as a means of religion. These new Churches, however, are supported by an interest group located in the so called Bible belt in the United States of America. There spread in Nigeria is so palpable that it needs no commentary. Their appeal to the youthful seekers of fortune is thereby understandable. However, it is ironical that some Nigerian men of God have gallantly deviated from the path and only pay lip service to the true essence of Christianity. The million dollar question remains, how does one 
accommodate the cross within the frame work of this religious vision?

\section{Search for Security}

Search for security is a phenomenon pushing people around in the quest for healing and solutions to mysterious problems such as freedom from sinister forces that threaten life in African society. Ndiokwere (1994) believes that as long as one is not in the position to control certain spiritual forces one describes as diabolical, one is bound to feel insecure. Surrounded by hostile forces, seen and unseen, menacing him and often the entire household, the African will cross rivers and mountains in search for answers to his problems. In this type of religious vagrancy, he rarely discriminates. He does not worry about the type of religion he joins. His main preoccupation is to achieve success, get a reasonable solution to his problem. Misfortune often pushes him to an extreme corner. Thus, search for security has contributed to a large extent to growing number of the healing Churches in Nigeria. However, Emesowum (2007) remarks that "the Jehovah's witnesses will say that it is well known-that the world is in its end time, people should head to the warning by Christ concerning the end time, miracles are being advertised everywhere to trap man" (p. 159).

In Nigeria today, many people most especially the new religious founders have become prophets and prophetesses, claiming to see beyond the future and predict the past and present situation of people in the society. Clamour for miracles, signs and wonders in our society have become a notice board of many new generation Churches as a means of imitating Christ, doing what Christ urged His apostles to do before He gave up. Many pastors, evangelists and prophets have acquired many radio stations, television, social media, magazines and newspapers for the advert of their miracles, 
signs and wonders that they are performing in the Churches, some of them now device modern way of preaching the gospel using the media at the market squares and making emphasis on the things that concerns family problems because they know that these problems are the week point of most of the families who are their audience.

\section{Excommunicated Members from the Mainline Churches}

Dafiewhare (2008) says that it was also realized that most of the founders of the new generation Churches capitalize on little crisis and sees an opportunity to establish their own business or ministries. The fear of being disciplined or suspended from the mainline Churches for erring members was equally discovered as a means for secession. There are some ministries in Nigeria even beyond which are founded by excommunicated members from the established Churches. Such erring members often claim that it is God who has called them to move out from the mother Church. A lot of litigations and accusation will be blown into the air. This ought to be uncalled for by fellow believers in the house of God. It is very shameful, unholy and unchristian.

\section{Socio-Religious Factor}

Religious factor is strictly theological in nature which had contributed immensely to the global Pentecostal movement in the society. These religious drives are geared towards the attainment of satisfying religion. However these new religious sects are characterized with new scriptural doctrines and also new liturgy which they often claim had been overlooked by the older Churches. This religious grouping of Africa shows the understanding of Africans about God which may largely have originated as a result of the publication of the scriptures in African languages. Madu (2003) assertion that religion is an enigma is a truism, and this 
significant feature of religion cannot be divorced from the spectrum of the magnetic field which religion claims to be its operational base. This is the realm of the extra-mundane, the transcendental, nay the supernatural beings. According to Nmah (2005) "this religious factors denotes a new movement and the attainment of a satisfying religion; it is characterized by new doctrine, liturgy and new political structure" (p. 8). These observations show that the founders of these new Christian denominations often tend to give new and sometime bizarre interpretations to the scripture as new revelations from God often to suit particular situations that they may wish to highlight.

\section{The Costs of Proliferation of Churches in Nigeria Family/Societal Disintegration}

The establishment of new Independent Churches in our contemporary Nigerian society has been an instrument of disintegration in our society. Due to the existence of some new religious movements, some parents now find it very difficult to curb the religious zeal of their children. In some families as the case may be, some of their children had decamped from their parent's Churches. No one can doubt whether this is surely a sense of family disintegration in our society. More worrisome is the fact that the larger society is now polarized along denominational lines. There is no gainsaying the fact that Christians are now against fellow Christians in any political or even socio-economic contest. What one gets in the society today is largely determined by his or her religious cum denominational affiliation irrespective of his or her qualification. Denominational divide even in the dominant Christian regions of the country is only second to ethnicity such that the issue of ecumenism has degenerated to mere lip service, and this demands the urgent attention of theologians and religious scholars especially now that the 
Christians are expected to be united in the face of the current ethno-religious extremism in the country.

\section{'Mushroom' Churches}

The explosion of global Pentecostalism in Nigeria has made many overzealous pastors to open Churches in small apartments and call themselves "General Over -Sears". Even some of those founders have no hope of survival before they opened to themselves Churches. They may be either sacked from their work places or excommunicated from other Churches which the only option they think that is left for them was to open up a mushroom Church. This multiplication of Christian groupings in Nigeria has reached an alarming proportion. There is now what may be defined as a scramble for time, space and converts by the various Christian movements as they struggle for relevance. In Nigeria now, all corners of the streets, family houses, schools and offices most especially among students of different tertiary institutions have been infested with new religious beliefs and teachings. It is for this that Okafor (2005) warns that "the noticeable mushrooming of prayer groups and Churches today; is imperative on all to be on their guard against all these rampaging pastors and ministries looking for whom to deceive" (p. 97).

\section{Denominational Rivalry and Intolerance among Christians}

The incidence of Christian rivalry in Nigeria is not a new phenomenon, and it has been with us for centuries. The rise of nationalism in Europe was accompanied by state actions that led to eviction of religious communities that did not subscribe to established religion. In Nigeria, the problem that followed the denominational Christians and rivalry among Christians of different Churches are characterized by 
envy, hatred, jealousy with which the missionaries carried out their evangelism. This had affected the moral and spiritual growth of the Christians. Kalu (1978) says that:

The rivalry boils down to rivalry between the C.M.S. (Ajayi Crowther, Simon Jonas, a liberated slave of Igbo parentage, Archdeacon Dennis the missionary scholar who created union Igbo for the purposes of Igbo Bible translation, and the Roman Catholic mission (Father Shanahan among others); and it centred on Onitsha and Owerri. (p. 305).

Therefore, Christians have currently used their emotional appeal of religion to step into political power or competition to create an environment of hostility, discrimination, hatred in the society.

\section{Commercialization of the Good News}

Commercialization is a process or cycle of introducing a new product or service into the market. Now, some founders of the new Independent Churches are now commercializing the gospel in the name of preaching the word of God to people at market squares, buses and their Churches in their own interest. But what is very obvious in their preaching is that, those pastors of new religious groups and equally some new converts today that devote themselves to preach the word of God outside the Churches always make emphasis on money while preaching to people at to market or bus. They always make use of certain words to deceive people because they want money from them. That Jesus admonishes, freely you have received, freely you give (Matt 21:18) without even minding that what Jesus meant when he said these is to help human being to resist the temptation to commercialize religion. But despite this injunction, many of the founders of these new Independent Churches have not been able to resist the reality that they had made religion a source of 
merchandize. Obiora (1998), has described the commercial tendencies of these new religious groups as "Holy Deceit", the art of trading in God's name, willing to commercialize religion for their own benefits and interests" (p. 88), yet some are still using religion as a lucrative business avenue to maximize profits.

\section{Environmental Pollution}

Proliferation of Churches in Nigeria is not only a social embarrassment but has constituted a source of serious worry through its religious activities. Most often, members of these new religious groups tend to practice their religion without considering its impacts on the immediate environment. They often embark on noisy religious activities with the loudest public address systems even when the Church is in one room apartment. More worrisome is their night vigils which some of them hold almost every day as if God hear prayers only at nights. In some areas in the society where there are many of such Churches, the experience of the people within the neighbourhood can only be imagined and any attempt to persuade the pastors to consider the feelings of the people is often interpreted as the devil's intervention that must be matched with fiercer and nosier prayers to combat the enemy.

\section{Some Benefits of Proliferation of Churches in Nigeria Proper Self-Examination}

The proliferation of Churches has made the authorities of the mainline Churches to sit up properly and re-examine their mode of operation. Thus, the authorities are challenged to welcome new, ideas, information and avoid stereotypes. Nmah (2008) say that "one of the positive effects of the proliferation of religion in the society is that, it has made the mother Churches to wake up from their spiritual slumber" (p. 43). Every Church is struggling to avoid reliving some 
challenges and difficulties that faced them in the past which may have resulted in the secession of sizeable members of the congregation. Every human organization is usually prone to problems at one time or the other. The ability to promptly address such problems will definitely swallow up the violence without necessarily disintegrating the organization. Perhaps the Church as a human organization cannot be free from the humanness in her. Any sensed impending crisis must now be handled at once so that it does not escalate since the inability to treat issues of that nature quickly can result in secession in the Church of God.

\section{Encouragement of Missionary Commitment}

Proliferation of Churches is one of the issues that bring about missionary commitment in the existing Churches. The presence, message and operations of modern Pentecostal movements are real challenges to the traditional Churches. The Churches have now more than before an obligation to live, pray, believe, work and love in such a way that their relevance in the face of Pentecostal onslaught can always be appreciated. Sometimes the liturgy of the mainline Churches is being adjusted to suit the exigencies of the wider society and by so doing the tendency for secession is curtailed.

\section{Expansion of the Christian Gospel}

This is another positive effect of proliferation of Churches in Nigeria. It has led to the rapid competition of different doctrines and expansion of Christianity to every nook and cranny in our country. That is, it has lessened the tedious task of evangelizing in Nigeria by only the frontlines Churches. This is particularly important considering that one of the factors that inhibited the spread of the gospel in Nigeria during the missionary era was lack of indigenous personnel, and since the initiative of the new religious movements often 
come from Nigerians themselves, it has helped in taking the gospel to even the remotest parts of the country. Sometimes crusades and Church retreats are conducted in the villages which predisposes the villagers to having direct asses to the gospel. Again, since almost all the cities are filled up with Churches, it seems that the only procreant grounds for the establishment of new Churches are the remote areas.

\section{Conclusion}

Looking at the effects of the proliferation of Churches in Nigeria, it seems to have brought more chaos and disadvantages than the expected gains that religion is expected to offer, this is because one of the purposes of religion is to bring succor to mankind but in our own idea and worldview it is relatively subjective. That is why recently through the media the westerners regard African preachers as opportunists because they believe that most of our preachers go into Church not because of any divine mandate, but because they see Church opening as a business venture. Most of these preacher are not interested in salvaging the ugly situation at hand as the good shepherd, but rather, they go on extorting money from the members both from the rich and the poor, those who are ignorant of the business of the so called men of God, that their business is business of deception, business of getting themselves rich through the ignorant members, buying private jets flashy cars, building executive lodges, fall easy prey to their antics. However, there is no gainsaying the fact that Church proliferation in Nigeria could be a blessing if properly managed and guided. What is required now from the founders of new Independent Churches is to attend Bible school or schools of theology before they can carry out any preaching or teachings of the Church. This is because a situation, where by Bible teaching is used to emphasize material wealth as some of the founders do today, can easily 
abolish the Christian values or interest in the Bible. But sound teaching of the Bible can promote faith, hope to the members and both spiritual and physical sound doctrine.

Again there is the urgent need among the mainline Churches to look at the necessity of readdressing the orthodox liturgy without altering the substance of it. This will make the liturgy to be very relevant to the Nigerian contemporary society. More so, the dullness and orthodoxy of the frontline Churches should be reviewed. And this will enhance the usage of the liturgy and equally make it to be vibrant in line with current societal demands of the new generation Christians. Christians in our modern society are tired of the old system of the liturgy in the long established Churches. And this has been one of the reasons why some members used to formulate flimsy excuses and decide to secede under the guise of "God has called me". Thus, if the mainline Churches can adopt this step of revisiting the old liturgy, then the tendency to lose membership will be checked to a great deal. Usually new ideas can easily carry the youths away. Therefore, it requires investigation of the liturgical in most of the old Churches.

Finally, Ecumenism should be intensified since the phenomenon of Church proliferation has come to stay with us. Indeed Churches should be more united and have the goal of winning souls for Christ. They should always make their emphasis on the things that hold members together rather than what will divide them or separate them, because Christ himself is a peace maker not a destroyer.

\section{B.A.C. Obiefuna, K.L. Nwadialor\& I.L. Umeanolue Department of Religion and Human Relations Nnamdi Azikiwe University, Awka, Nigeria}

\section{References}


Amucheazi, E.C. (1986). Church and politics in eastern Nigeria, 1945-1966: A study in pressure group politics. Ibadan: Macmillan.

Brian, J. G. (2012). Rising restrictions on religion: Context, statistics and implications. International Journal of Religious Freedom. 5. 1. 26-32.

Dafiewhare, U.A.A. (2008). The proliferation of Churches in Nigeria: The Niger Delta experience. Ugheli: Johimp.

Ekechi, F.K. (1972). Missionary enterprise and rivalry in Igboland, 1857-1914. London: Frank Cass.

Emesowum, C.K. (2007). Doctrinal conflicts in Christendom: Which way forward. Umuahia: Atlanta.

Essien, A.M. (2010). Proliferation of Churches: A Lee way to commercialization of religion. European Journal of Scientific Research, 201, 4, 1-45.

Hasting, A. (1976). African Christianity: An essay in interpretation. London: Geoffrey Chapman.

Iwe, N.S.S. (1991). Socio-ethical issues in Nigeria. Obosi: Pacific.

Kalu, O.U. (1978). Church unity and religious change in Africa. In L. Fashola (Ed.). Christianity in independent African (pp 33-40). Ibadan: University of Ibadan.

Madu, J.E. (2003). The paradox of the "one" and the "many" in religion. Nkpor: Globe.

Mbefo, L.N. (2002). The true Africa: Impulses of self affirmation. Onitsha: Spiritan.

Ndiokwere, N.I. (1994). The Nigerian Church today and tomorrow. Vol.1: Prospects and challenges. Onitsha: Effective Key.

Nmah, P.E. (2008). Religion and society in Africa. Enugu: RABBONI. 
Nmah, P.E. (2010. Christian missionaries and socio-economic development in colonial West Africa, 1814-1960: A challenge to global evangelism in the third millennium. In A.B.C. Chiegboka, T.C. UtohEzeajugh \& G. Udechukwu (Eds.). The humanities and globalization in the third millennium (pp. 240247). Nimo: Rex Charles and Patrick.

Nwadialor, K.L. \& Umeanolue, I.L. (2013). Materialistic gospel message in contemporary Nigerian Churches: A critique. Journal of Religion and Human Relations, 1, 5, 29-44.

Obiora, F.K. (1998). The divine deceit in religion. Enugu: Optimal.

Okafor, V.E. (2008). The noticeable mushrooming of prayer groups and Churches: Journal of Religion and Human Relations, 1, 1, 97-99.

Trigg, R. (2012). Religious freedom in a secular society. International Journal for

ReligiousFreedom. 5. 455-457. 